\title{
BÁO CÁO CA BÊ̂NH: HộI CHỨNG GAN PHỔI Ở TRẺ XƠ GAN
}

\author{
Nguyễn Phạm Anh Hoa*, Bùi Thị Hương Thùy*, Phạm Thị Hải Yến*, \\ Cao Việt Tùng*, Vũ Thị Dinh*, Hoàng Văn Tám*, Đỗ Văn Đô*, \\ Trịnh Thị Thủy*, Trần Thị Dự*, Nguyễn Đỗ Phương Thúy*
}

\section{TÓM TẮT}

Hội chứng gan phổi (Hepatopulmonary syndromeHPS) là một biến chứng hiếm. Tî lệ xuất hiện từ 4\%$40 \%$ trên bệnh nhi xơ gan. Chẩn đoán xác định HPS dựa vào bộ ba gồm bệnh gan mạn tính, giảm oxy máu và bất thường mao mach phổi. HPS được coi là tiên lượng xấu đối với bệnh nhân xơ gan. Các biện pháp điểu trị hỗ trơ trong thời gian chờ ghép gan bao gồm oxy liệu pháp, các thuốc có tác dụng giúp co mạch phổi, một số thủ thuật như TIPS. Trong phạm vi bài báo này, chúng tôi báo cáo một trường hợp một trẻ nữ 15 tuổi xơ gan có biến chứng tăng áp lực tĩnh mạch cửa kèm theo hội chứng HPS. Chẩn đoán xác định bằng siêu âm tim cản âm, chụp xa hình tưới máu phổi giúp tiên lượng và lập kế hoạch điều trị

Ti̛ khóa: Hội chứng gan phổi, xơ gan, siêu âm tim cản âm

\section{SUMMARY \\ HEPATOPULMONARY SYNDROME IN CHILREN WITH CIRRHOSIS}

Hepatopulmonary syndrome (HPS) is a rare complication. The rate appears from $4 \%-40 \%$ in patients with cirrhosis. HPS is charactezied by the triad of chronic liver disease, abnormal arterial oxygenation congenital portosysmic shunts. HPS is considered a poor prognosis in cirrhotic patients. Supportive treatments pending a liver transplant include oxygen therapy, medications that help with pulmonary vasoconstriction, and some procedures such as TIPS. For the purposes of this article, we report a case of a 15-year-old female with cirrhosis of the liver with complications of portal hypertension with HPS syndrome. Diagnosis confirmed by transthoracic contrast echocardiography, contrast pulmonary angiography helps prognosis and reasonable treatment plan.

Key words: Hepatopulmonary syndrome, cirrhosis, transthoracic contrast echocardiography

\section{BÁO CÁO CA BỆNH}

Bệnh nhân nữ 15 tuổi, nhập viện do có tình trạng lách to và chức năng gan bất thường trẻ tỉnh táo, thể trạng suy dinh dưỡng với BMI 16, chậm phát triển trí tuệ mức độ trung bình với test IQ (60 -65), phổi thông khí rõ, không có ran, bụng mêm, gan không sờ thấy dưới bờ sườn

*Bệnh viện Nhi Trung Uơng

Chịu trách nhiệm chính: Nguyễn Phạm Anh Hoa

Email: dranhhoa@gmail.com

Ngày nhận bài: 20.10.2020

Ngày phản biện khoa học: 24.11.2020

Ngày duyệt bài: 11.12.2020 phải, lách $4 \mathrm{~cm}$ dưới bờ sườn mật độ chắc, không có móng tay khum, không có ngón tay dùi trống, hê thống tim mach bình thường. Tuy không có các bất thường về hô hấp và tim mạch trên thăm khám thông thường nhưng bệnh nhân luôn có tình trạng khó thở, tím môi và đâu chi. Đo $\mathrm{SpO} 2$ ở tư thế nằm $60 \%$, SpO2 tư thế ngồi $62 \%$.Tình trạng thiếu oxy cải thiện tốt sau thở oxy mask 5 lít/phút song chỉ đạt tới $90-92 \%$. Khai thác tiền sử, bệnh nhân có tiền sử chẩn đoán và điều trị động kinh từ lúc 5 tuổi, kiểm soát cơn giật tốt, chậm phát triển trí tuệ từ nhỏ, me ruột có HbsAg dương tính, trẻ chưa được thăm dò các xét nghiệm về chức năng gan trước đó.

Các xét nghiệm cho thây bạch câu $5.32 \mathrm{G} / \mathrm{L}$ và tiểu cầu giảm $57 \mathrm{G} / \mathrm{L}$, tăng transaminase với GOT 96UI/L, GPT 34 UI/L, ure và creatinine trong giới hạn bình thường $3,6 \mathrm{mmol} /$ lít và 40 $\mathrm{mmol} /$ lít).Chức năng đông máu Prothrombin $62 \%$, INR 1,41, APTT 42,5s, Fibrinogen $2.04 \mathrm{~g} / \mathrm{L}$, Albumin $32.5 \mathrm{~g} / \mathrm{L}$, protid máu $61,7 \mathrm{~g} / \mathrm{L}$. Các xét nghiệm vi sinh $\mathrm{HBsAg}$ dương tính, $\mathrm{HBeAg}$ dương tính và HBV DNA 44000 copies/ml. Phân tích trên khí máu động mạch cho thây tình trạng suy hô hấp type 1 với $\mathrm{PO} 2$ là $39 \mathrm{mmHg}, \mathrm{AaDO} 2$ (chênh áp lực riêng phần oxy phế nang - động mạch) = 78,23. Siêu âm ổ bụng có hình ảnh lách to, chiêu dài dọc lách 136 mm, gan nhu mô không đều, bờ gan không đều, teo hạ phân thùy IV. Thăm dò hình ảnh về hô hấp trển phim XQuang ngực thẳng không có hình ảnh viêm phổi chỉ thấy tăng đậm khoảng kẽ vùng đáy và mạch phổi.

Tình trang lâm sàng và xét nghiệm cơ bản cho thấy tình trạng tốn thương gan mạn tính. Bệnh nhân được tiếp cận chẩn đoán xác định các biến chứng của tình trạng bệnh gan mạn tính, tình trạng tăng áp lực tînh mạch cửa và nguyên nhân thiếu oxy.

Siêu âm Doppler mạch gan và tĩnh mạch cửa cho thây các dấu hiệu gián tiếp của hội chứng tăng áp lực tĩnh mạch cửa với. Nghi ngờ này được khẳng định bẳng kết quả nội soi dạ dày thực quản vớigiãn tĩnh mạch thực quản độ 2, kèm theo viêm toàn bộ niêm mạch dạ dày. Chụp cắt lớp vi tính lồng ngực độ phẩn giải cao không có hình ảnh bất thường, siêu âm tim cho thây phân suất tống máu khoảng $59 \%$ với chức năng tâm thu thất trái bình thường giúp loại trừ các 
nguyên nhân thiếu oxy do bệnh lý phổi thông thường. Tình trạng suy hô hấp mạn tính có thích nghi ở bệnh nhân có tổn thương gan mạn tính, xơ gan, tăng áp lực tĩnh mạch hướng nhiều tới do các tổn thương trong hội chứng gan phổi. $\mathrm{S}$ iêu âm tim đối quang và chụp xạ hình tưới máu phổi được tiến hành giúp chẩn đoán HPS.

Siêu âm tim cản âm (siêu âm tim đồi quang).

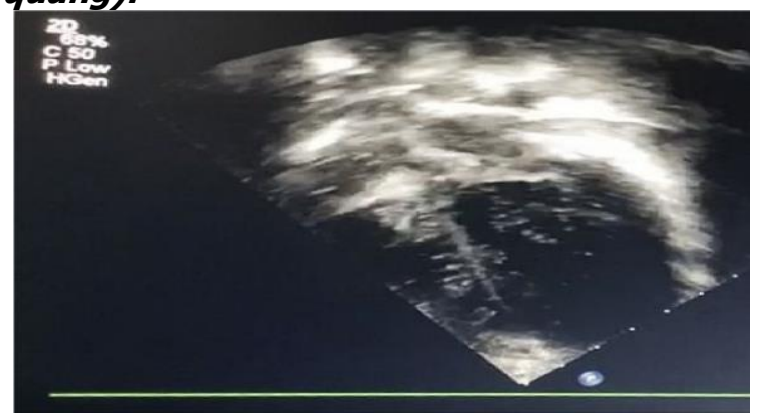

Hình ảnh tĩnh từ siêu âm tim đối quang của bệnh nhân cho thây xuất hiện hình ảnh bóng khi xuất hiện tại tm nhĩ và tâm thất trái sau 3 chu kỳ tim, biểu thị cho tình trạng shunt trong phổi.

Xa hình tưới máu phổi . Dùng các thể tụ tập albumin huyết thanh người Macroaggregated albumin (MAA) đánh dấu phóng xạ Technetium

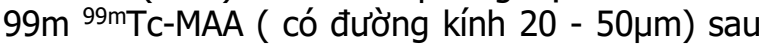
khi tiêm tĩnh mạch sẽ theo dòng máu đến nhĩ phải, thất phải, vào động mạch phổi đến mao mạch phổi. Các hạt này sẽ gầy nghẽn tạm thời các động mạch nhỏ và mao mạch ở phổi (đường kính bình thường $8-15 \mu \mathrm{m}$ ), sau đó sẽ thoát ra và được tiêu hủy theo cơ chế thực bào, do đó có thể ghi hình được sự phân bố của các mao mạch phổi. Ở những bệnh nhân hội chứng gan phổi (HPS) các mao mạch phổi giãn ra có đường kính lên đến $100 \mu \mathrm{m}$. Các hạt ${ }^{99 \mathrm{~m} T c-M A A}$ này dễ dàng đi qua các mao mạch phổi bị giãn và đi vào hệ tuân hoàn để bị giữ lại trong các mao mạch kích thước bình thường của não, gan, thận và các cơ quan khác, tương ứng với nguồn cung cấp máu của chúng. Bệnh nhân khỏe mạnh bình thường, đồng vị có thể được định lượng trong não với lượng $<5 \%$. Ở bệnh nhân hội chứng gan phổi tỷ lệ này là trên $6 \%$. Ở bệnh nhân này (15 tuổi, cân nặng $26 \mathrm{~kg}$ ) chúng tôi sử dụng dược chất phóng xạ ${ }^{99 m T c}$ - MAA, liều ${ }^{99 m T c} 0,8 \mathrm{mCi}$, số hạt MAA: 200-300 nghìn hạt, tiêm tĩnh mạch chậm.

Sử dụng máy ghi đo: máy SPECT Siemens.

Dùng chuẩn trực độ phân giải cao, năng lượng thấp (LEHR) và ma trận 256 × 256 .

Các thời điểm ghi đo:

+ Ghi hình động (Dynamic) phổi: ghi ngay sau tiêm, ghi 3 giây/hình x 20 hình
+ Ghi hình tĩnh (Static) phổi và não: ngay sau ghi hình động, ghi 5 phút/hình (700 kcounts/ hình) với các tư thế: phổi thẳng trước - thẳng sau, não nghiêng phải - nghiêng trái, toàn thân thẳng trước - thẳng sau.

Kết quả: Hoạt độ phóng xạ tập trung cao nhất tại hai phổi (phổi phải tập trung cao hơn phổi trái), ngoài ra hoạt độ phóng xạ tập trung cao ở tuyến giáp, dạ dày, lách, hai thận, não.
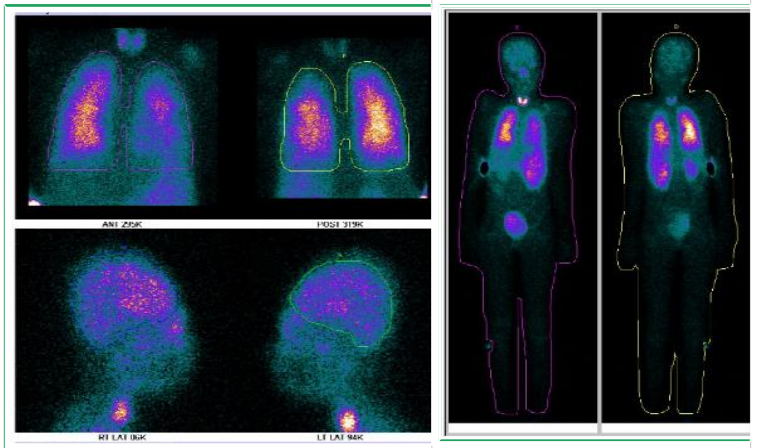

Số xung ở hai phổi: 191 Kcounts, số xung ở não: 34 Kcounts, số xung ở toàn cơ thể: 313 Kcounts. Tỷ lệ phần trăm shunt phổi- não: $15 \%$. Tỷ lệ phần trăm shunt phổi- toàn cơ thể: $39 \%$

ớ ca bệnh này tỷ lệ hấp thu Tc $99 \mathrm{~m}-\mathrm{MAA}$ ở não là $15 \%$, tỷ lệ hấp thu toàn cơ thể là $39 \%$ cho phép kết luận bệnh nhân có shunt phải trái do hội chứng gan phổi. Chẩn đoán xác định bệnh nhân có tình trạng xơ gan có biến chứng tăng áp lực tĩnh mạch cửa và hội chứng gan phổi trên nền bệnh lý động kinh và chậm phát triển tinh thần mức độ trung bình. Bệnh nhân được điều trị hỗ trợ tình trạng xơ gan và các biến chứng của xơ gan, tiếp tục điêu trị động kinh và sử dụng oxy liệu pháp giúp cho tình trạng oxy trong máu của bệnh nhân được cải thiện và giữ ổn định ở mức an toàn và tiếp tục liệu pháp hỗ trợ oxy tại nhà.

\section{BÀN LUẬN}

Hội chứng gan phổi (Hepatopulmonary syndrome - HPS) là một trong những biến chứng của xơ gan, đặc trung bởi tam chứng bệnh gan mạn tính, giảm oxy máu động mạch, giãn mạch máu phối [1], [2]. Xơ gan và tăng áp lực tînh mạch cửa là các tình trạng thường kết hợp với HPS. Tiêu chuẩn chẩn đoán HPS theo European Respiratory Society 2004: có bệnh lý gan mạn: Gradient oxy phế nang - động mạch > $15 \mathrm{mmHg}$ (hoặc > 20mmHg nếu > 65 tuổi) và/ hoặc áp lực riêng phần oxy máu động mạch $(\mathrm{PaO} 2)<$ $80 \mathrm{mmHg}$ và có bằng chứng về sự giãn bất thường mạch máu phổi; không có bệnh tim phổi khác. 
Mặc dù hội chứng gan phổi có thể phối hợp với cả bệnh lí gan cấp và mạn tính, tuy nhiên thường gặp nhiều hơn ở bệnh nhân xơ gan, đặc biệt là các bệnh nhân xơ gan có biến chứng tăng áp lực tĩnh mạch cửa và là một trong những biến chứng nặng của xơ gan. Những thay đổi mạch máu ở phổi trong bệnh lí gan phổi là hậu quả của nhiêu nguyên nhân như giãn mạch ở tiền mao mạch và tại mao mạch, sự thông thương trực tiếp giữa động mạch và tînh mạch. Hiện tượng tạo shunt phải - trái ở mạch máu dẫn đến sự rối loạn trao đổi khí.

Triệu chứng lâm sàng của HPS khá đa dạng, bao gồm cả các triệu chứng của bệnh gan mạn tính và các triệu chứng của tình trạng thiếu oxy mạn như ngón tay, ngón chân dùi trống, xanh tím trung tâm và ngoại vi. Khó thở và xanh tím là các triệu chứng thường gặp nhất. Khó thở và ngón tay dùi trống là các triệu chứng đặc trưng và dễ nhận biết trên lâm sàng. Khó thở khi ở tư thế đứng hoặc ngồi và hết khi nằm (platypnea). Tình trạng thiếu oxy máu động mạch ở tư thế đứng hoặc ngồi và hết khi nằm (orthrodeoxia). Tình trang này xuất hiện với tỷ lệ từ $5-88 \%$ ở bệnh nhân xơ gan nhưng thường thấy hơn ở những bệnh nhân có tình trạng thiếu oxy máu trầm trọng trong hội chứng gan phổi. Tuy vậy triệu chứng này không phải là triệu chứng đặc trưng của hội chứng gan phổi. Các triệu chứng khó thở và thiếu oxy ở tư thế đứng này được cải thiện sau khi ghép gan. Bệnh nhân có sao mạch dưới da có nguy cơ cao giãn mạch hệ thống và mạch phổi, hay có bất thường về trao đổi khí. Sự xuất hiện đồng thời tăng áp lực tĩnh mạch cửa, sao mạch ở da, ngón tay dùi trống và thiếu oxy máu trên lâm sàng có thể coi là các triệu chứng gợi ý hội chứng gan phổi.

Giảm oxy máu là chỉ điểm quan trọng của hội chứng gan phổi. Giảm oxy máu nhẹ là đặc điểm phổ biến của bệnh gan mạn tính, nó xuất hiện ở 1/3 số bệnh nhân. Ngược lại, giảm oxy máu nặng $(\mathrm{PaO} 2<60 \mathrm{mmHg})$ ít gặp ở bệnh nhân xơ gan đơn thuần mà thường kết hợp với bệnh tim phổi, đặc biệt khi có tình trạng giảm oxy máu động mạch nặng. Naeije và cộng sự nghiên cứu ở 100 bệnh nhân xơ gan nặng thì $28 \%$ có $\mathrm{PaO} 2$ $<70$ mmHG nhưng chỉ $8 \%$ có PaO2 < 60 $\mathrm{mmHg}$, đối chiếu với siêu âm tim có tăng độ cản quang đều có shunt trong phổi.

Việc đánh giá tình trạng oxy máu động mạch qua $\mathrm{PaO} 2$ và $\mathrm{AaDO} 2$ rất quan trọng trong việc phân chia giai đoạn của hội chứng gan phổi vàcó ý nghĩa tiên lượng, dự báo nguy cơ khi chỉ định ghép gan. $\mathrm{PaO} 2<50 \mathrm{mmHg}$ : Rất nặng. 50
$\mathrm{mmHg}<\mathrm{PaO} 2<60 \mathrm{mmHg}$ : Nặng. $60 \mathrm{mmHg} \leq$ $\mathrm{PaO} 2$ < 80 mmHg: Nhẹ, vừa. AaDO2 (chênh áp áp lực riêng phần oxy phế nang - động mạch): Nhạy hơn trong xác định sớm giảm oxy động mạch.

$\mathrm{AaDO} 2=\mathrm{PAO} 2-\mathrm{PaO} 2$

$\mathrm{PAO} 2=\mathrm{FiO} 2 \times(\mathrm{PB}-\mathrm{PH} 2 \mathrm{O})-\mathrm{PACO} 2 / \mathrm{k} \mathrm{PB}$ : áp suất khí quyển $(760 \mathrm{mmHg})$.

PH2O: áp suất hơi nước bão hòa $(47 \mathrm{mmHg})$

$\mathrm{PACO} 2=\mathrm{PaCO} 2, \mathrm{k}=0,8$

Bình thường (lúc nghỉ ngơi và thở trong điều kiện khí phòng) $\mathrm{AaDO} 2<15 \mathrm{mmHg}$, và $<20$ $\mathrm{mmHg}$ (ở người > 60 tuổi). Xét về $\mathrm{PaO} 2$, bệnh nhân trong ca bệnh này thuộc nhóm nặng và AaDO2 là 78,23, cao hơn gấp 3 lần so với giới hạn bình thường.

Cơ chế gây giảm oxy máu động mạch ở bệnh nhân xơ gan và bệnh nhân hội chứng gan phổi đang còn nhiều tranh cãi. Có nhiều giả thiết như sự thay đổi ái tính của hemoglobin đối với oxy; shunt phải - trái: Sự thông thương trực tiếp giữa động mạch- tĩnh mạch, nếu nhiều sẽ gây thiếu oxy máu nặng, không hồi phục khi thở oxy $100 \%$, và giãn mạch máu trong phổi được coi là nguyên nhân chính.

Giãn mạch máu trong phổi ở bệnh nhân xơ gan và hội chứng gan phổi gặp ở 13 - 47\% bệnh nhân xơ gan giai đoạn cuối và $10 \%$ ở bệnh nhân không có giảm oxy máu ở giai đoạn sớm của xơ gan. Bình thường, đường kính mao mạch phổi khoảng 8 -15micromet, khi thở ở không khí phòng, oxy từ các phế nang phân bố một cách nhanh chóng vào mao mạch, oxy hóa được cả những tế bào hồng cầu ở dòng chảy trung tâm. Trong hội chứng gan phổi, đường kính các mao mạch, giãn từ 15- 100 micromet, oxy từ phế nang không thể khuếch tán vào trung tâm của các mao mạch phổi để oxy hóa hemoglobin của tế bào hồng cầu ở dòng chảy trung tâm mao mạch.

Mặc dù nguyên nhân của giãn mạch trong hội chứng gan phổi vẫn còn chưa được biết rõ, các giả thiết về cơ chế bệnh sinh như sự giảm giáng hóa các chất làm giãn động mạch phổi như prostagladin, calcitonin, glucogon, nitric ocide, substance $P$, yếu tố hoạt hóa tiểu cầu ở các bệnh nhân xơ gan, trong khi các chất như tyrosine, serotonin, endothelin 1 có tác dụng co mạch lại giảm sút. Sự giảm đáp ứng của mạch đối với angiotensin II cũng là triệu chứng hay gặp ở bệnh nhân xơ gan. NO là chất giãn mạch mạnh, không bền, khả năng tái hoạt động cao, khí có thể khuếch tán, được sản xuất bởi nhiêu mô, đặc biệt là tế bào endorthelin lòng mạch và tế bào thần kinh là nguyên nhân chính gây giãn mạch trong xơ gan mất bù. ở bệnh nhân có hội chứng 
gan phổi NO thường tăng.

Để chẩn đoán hội chứng gan phổi, có thể tiếp cận ban đầu bằng các xét nghiêm: Khí máu động mạch ở tư thế nằm ngửa, bệnh nhân trong tình trang ổn định và thở khí phòng. $\mathrm{AaO} 2>20$ $\mathrm{mmHg}$ và hoặc $\mathrm{pO} 2<70 \mathrm{mmHg}$ [3]. Một nghiên cứu tiến cứu với 98 bệnh nhân quan sát thấy tỷ lê mắc HPS là $32 \%$ khi giá trị $\mathrm{AaO} 2$ cut off là $\geq$ $15 \mathrm{mmHg}, 31 \%$ khi $\mathrm{AaO} 2>20 \mathrm{mmHg}$ và $28 \%$ khi tính $\mathrm{AaO} 2$ theo tuổi. Nghiên cứu này cũng chỉ ra nếu sử dụng $\mathrm{PaO} 2$ thì độ nhạy kém hơn so với HPS [4].

- Test oxy: Nếu bệnh nhân đáp ứng với thở oxy và tăng $\mathrm{PaO} 2>60 \mathrm{mmHg}$, có thể loại trừ shunt. $\mathrm{PaO} 2$ ở mức $50 \mathrm{mmHg}$, nghi ngờ shunt. $\mathrm{PaO} 2$ ở mức $15-20 \mathrm{mmHg}$, shunt gần như chắc chắc là cơ chế thiếu oxy máu động mạch. Nếu shunt là nguyên nhân của thiếu oxy máu thì tình trạng thiếu oxy máu sẽ không được cải thiện sau khi ghép gan

Siêu âm tim cản âm: Là test sàng lọc tốt nhất để chẩn đoán giãn mạch phổi. Đây được coi là tiêu chuẩn vàng để chẩn đoán HPS [5].

- Ghi hình bằng Tech $99 \mathrm{~m}$ gắn albumin: Là phương pháp tốt để chẩn đoán giãn mạch phổi. Tiêm Tech $99 \mathrm{~mm}$ gắn albumin vào tĩnh mạch ngoại vi. Albumin có kích thước từ $20-50$ microm, không qua được mao mạch phổi bình thường $D=8-15$ micromet, song có thể qua được mạch phổi giãn, tích tụ trong các cơ quan khác như não, thận, lá lách và tuyến giáp. Ngoài ra phương pháp này cho phép đinh lương mức độ shunt trong phổi[6]. Đô nhay của kĩ thuật này thay đổi từ $20 \%$ đến $96 \%$, độ nhạy cao trong trường hợp nặng, thấp trong trường hợp trung bình nhe. Abrams GA và cộng sự sử dụng kĩ thuât này để thực hiên trên 25 bệnh nhân mắc HPS, 25 bệnh nhân xơ gan không có HPS và 15 đối tượng thiếu oxy do bệnh phổi nội tại cho thây kết quả dương tính ở 21 trong sổ 25 bệnh nhân mắc HPS và âm tính trong các trường hợp còn lại. Tất cả các bệnh nhân dương tính có giá trị trị PO2 < $60 \mathrm{mmHg}$ [7].

- Chụp động mạch phổi là phương pháp chẩn đoán có giá trị trong giãn mạch máu phổi, nhưng là biện pháp thăm dò có xâm lấn nên ít được dùng. Tuy nhiên phương pháp này giúp chẩn đoán phân type và tiên lượng điều trị. Type 1 loại khuếch tán đáp ứng với test oxy $100 \%$, đạt $\mathrm{PaO} 2>200 \mathrm{mmHg}$ sau test. Type 2 loại khu trú tương tự giống như dị tật thực sự, kém đáp ứng và biện pháp duy nhất để cải thiện là ghép gan.

Các bênh nhân có hội chứng gan phổi được theo dõi và điều trị tùy mức độ bệnh. Ở mức độ nhẹ đến trung bình: bệnh nhân cần được theo dõi tiến triển bệnh 6 đển 12 tháng một lần bằng phương pháp đo oxy qua khí máu, phân tích khí máu động mạch để xác định tình trạng xấu đi và đưa ra chiến lược điều trị tĩnh cực khác như ghép gan và/ hoặc bổ sung oxy. Việc bổ sung oxy chỉ cần thiết khi có tình trạng thiếu oxy do tập thể dục. Những bệnh nhân này sẽ được kiểm tra bằng nghiệm pháp đi bộ 6 phút định kì. Đối với bệnh nhân hội chứng gan phổi nặng hoặc rất nặng: Điều trị bằng bổ sung oxy dài hạn và lập kể hoạch ghép gan. Liệu pháp oxy chỉ cải thiện oxy khi mà có các bất thường liên quan đến shunt mạch máu trong phổi. Một số biện pháp can thiệp khác gồm TIPS, thuốc co mạch cũng được sử dụng nhưng chưa có nghiên cứu nào chỉ ra rõ ràng về hiệu quả. Liệu pháp ghép gan cho những bệnh nhẩn bị nặng hoặc rất nặng, được chứng minh là biện pháp điêu trị hiệu quả duy nhất với HPS giúp cải thiện tỉ lệ sống sót [8]. Ghép gan giúp giảm shunt đáng kể ở một số bệnh nhân. Pascasio và cộng sự quan sát thấy rằ ng tỉ lệ sống sót sau ghép gan là như nhau ở cả 2 nhóm bệnh nhân có và không có HPS[9].

\section{KẾT LUÂ̂N}

Hội chứng gan phổi được đặc trưng bởi sự hiện diện của bộ ba: Bệnh gan mạn tính, giảm oxy máu, bất thường vi mao mạch phổi. Đây là một biến chứng nghiêm trọng của xơ gan làm xấu đi tiên lượng của bệnh nhân xơ gan. Các bệnh nhân có bệnh lý gan mạn tính cần được tiến hành các biện pháp chẩn đoán sớm ngay khi có các triệu chứng lâm sàng như khó thở, xanh tím... Siêu âm tim có chất cản quang và chụp xạ hình phổi là các xét nghiệm có giá trị cao trong chẩn đoán xác định. Bệnh nhân xơ gan có hội chứng gan phổi có thời gian sống ngắn hơn so với nhóm xớ gan không có hội chứng gan phổi và cân được theo dõi chặt chể và ưu tiên trong danh sách chờ ghép gan. Trong thời gian chờ tạng ghép hoặc các trường hợp chống chỉ định ghép tạng, các bệnh nhân HPS cần được điều trị bảo tồn thông qua oxy liệu pháp.

\section{TÀI LIÊU THAM KHẢO}

1. Dinh- Xuan A.T, Naeije R (2004). The hepatopulmonary syndrom: NO way out?. Eur Respir J, 23, 661-662.

2. M.Bahtoei, M.D (2000). Hepatopulmonary syndrom. department of internal Medicin.

3. Krowka M.J., Wiseman G.A., Burnett O.L. và cộng sư. (2000). Hepatopulmonary syndrome: a prospective study of relationships between severity of liver disease, $\mathrm{PaO}(2)$ response to $100 \%$ oxygen, and brain uptake after $(99 \mathrm{~m}) \mathrm{Tc}$ MAA lung 
scanning. Chest, 118(3), 615-624.

4. Schenk P., Schöniger-Hekele M., Fuhrmann V. và cộng sư. (2003). Prognostic significance of the hepatopulmonary syndrome in patients with cirrhosis. Gastroenterology, 125(4), 1042-1052.

5. Rodriguez-Roisin R. và Roca J. (1997). Hepatopulmonary syndrome: the paradigm of liverinduced hypoxaemia. Baillieres Clin Gastroenterol, 11(2), 387-406.

6. Rodríguez-Roisin R. và Krowka M.J. (2008), Hepatopulmonary syndrome--a liver-induced lung vascular disorder. N Engl J Med, 358(22), 2378-2387.

7. Lasch H.M., Fried M.W., Zacks S.L. và cộng sự.
(2001). Use of transjugular intrahepatic portosystemic shunt as a bridge to liver transplantation in a patient with severe hepatopulmonary syndrome. Liver Transpl, 7(2), 147-149.

8. Swanson K.L., Wiesner R.H., và Krowka M.J. (2005). Natural history of hepatopulmonary syndrome: Impact of liver transplantation. Hepatology, 41(5), 1122-1129.

9. Pascasio J.M., Grilo I., López-Pardo F.J. và cônng sư. (2014). Prevalence and severity of hepatopulmonary syndrome and its influence on survival in cirrhotic patients evaluated for liver transplantation. Am J Transplant, 14(6), 1391-1399.

\section{PHƯƠNG PHÁP SẢN XUẤT MẪU NƯỚC TIỂU GIẢ ĐỊNH ỨNG DỤNG TRONG CHƯO'NG TRÌNH NGOẠI KIỂM TỔNG PHÂN TÍCH NƯớC TIỂU}

\section{TÓM TẮT}

Mục tiêu: Đánh giá chất lượng mẫu nước tiểu giả định sử dụng trong chương trình ngoại kiểm tống phân tích nước tiểu. Đánh giá tính đồng nhất và độ ổn đinh của bố mẫu đã sản xuất thử nghiêm theo tiêu chuẩn ISO GUIDE 35:2017. Phương pháp: Mẫu nước tiểu bình thường được sản xuất và làm nền để sản xuất bộ mẫu nước tiểu bất thường với những thông số (tỷ trọng (Specific Gravity - SG), pH, glucose (GLU), protein (PRO), urobilinogen (URO), bilirubin (BIL), nitrite (NIT), leukocyte (LEU), keton (KET), blood (BLO)) đã định trước. Đeánh giá tiên phân tích và đánh giá độ đồng nhất bộ mẫu trước khi chia thành 2 lô bảo quản ở 2 điều kiên nhiêt độ khác nhau là $2-8^{\circ} \mathrm{C}$ và $20^{\circ} \mathrm{C}$. Sau đó đánh giá độ ổn định dài hạn trong 3 tháng tại 6 thời điểm là 1 tuần, 2 tuần, 4 tuần, 6 tuần, 8 tuần và 12 tuần. Đánh giá độ ổn định ngắn hạn trong điều kiện vận chuyển sau 5 ngày, 8 ngày và 10 ngày gửi mẫu đển các phòng xét nghiệm tham gia. Kết quả: Sản xuất được mẫu nước tiểu giả đinh bất thường nhằm ứng dụng vào chương trình ngoại kiểm tổng phân tích nước tiểu10 thông số. Bộ mẫu sau khi sản xuất đạt độ đồng nhất (giá trị p các thông số đều lớn hơn 0.05). Mẫu nước tiểu sản xuất ra đạt độ ổn định trong thời hạn 3 tháng ởđiều kiện nhiệt độ $-20^{\circ} \mathrm{C}$ (p>0.05). Riêng bộ mấu giữ ở $2-8^{\circ} \mathrm{C}$, có LE் ổn định chỉ trong 6 tuần, URO ổn định trong 8 tuần, các thổng số SG, pH, GLU, PRO, NIT, KET, BLO ổn đinh trong 12 tuần $(p>0.05)$. Đối với độ ổn định ngẳn hạn, các thông số leukocytes, bilirubin và urobilinogen đạt độ ổn định trong thời gian 8 ngày vận chuyển, các thông

${ }^{1}$ Đai học y dượ Tp. Hồ Chí Minh

${ }^{2}$ Trung tâm Kiểm chuẩn chất lượng xét nghiệm Y học - Đai hoc Y Dước Tp. Hồ Chí Minh

Chịu trách nhiệm chính: Vũ Quang Huy

Email: drvuquanghuy@gmail.com

Ngày nhận bài: 19.10.2020

Ngày phản biên khoa hoc: 25.11.2020

Ngày duyệt bài: 9.12.2020
Vũ Quang Huy ${ }^{1,2}$, Lê Văn Chương ${ }^{1,2}$, Trần Nhật Nguyên ${ }^{2}$, Huỳnh Thị Diễm Phúc ${ }^{2}$

sỗ còn lại đạt độ ổn định trong thời gian 10 ngày vận chuyển ( $p$-value > 0.05). Kết luận: Xây dựng hoàn chî̉nh quy trình sản xuất mấu ngoại kiểm nước tiểu. Mẫu nước tiểu giả định đạt độ đồng nhất sau khi sản xuất. Đạt độ ổn định dài hạn trong vòng 3 tháng ở $20^{\circ} \mathrm{C}, 6$ tuần ở $2-8^{\circ} \mathrm{C}$, đạt độ ổn định ngắn hạn 8 ngày trong điều kiện vận chuyển mẫu sản xuất đủ điều kiện sử dụng cho chương trinh ngoại kiểm tổng phân tích nước tiểu.

Tư khóa: Tổng phân tích nước tiểu, ngoại kiểm, độ ổn định, độ đồng nhất.

\section{SUMMARY \\ PRODUCTION METHOD OF SIMULATED URINE UTILIZED IN URINALYSIS}

EXTERNAL QUALITY ASSESSMENT SCHEME

Objectives: To study methods of producing simulated urine samples used in external quality assessment (EQA) program. The homogeneity and stability of producing samples was evaluated according to ISO GUIDE 35:2017. Methods: Ten parameters (density (Specific Gravity-SG), pH, glucose (GLU), protein (PRO), urobilinogen (URO), bilirubin (BIL), nitrite (NIT), leukocyte (LEU), keton (KET), blood (BLO)) of normal urine sample were adjusted to produce abnormal urine sample with predetermined characteristics. The sets of producing samples were evaluated for pre-analysis and assessment of homogeneity then divided into 2 lots and stored at different temperature conditions $\left(2-8^{\circ} \mathrm{C}\right.$ and $\left.-20^{\circ} \mathrm{C}\right)$. The long-term stability is assessed for 3 months at 6 periods of time comprising: $1,2,4,6,8$ and 12 weeks. Sort-term stability was evaluated in the shipping conditions after 5, 8 and 10 days deliver to participant laboratories. Results: Two batches of simulated urine samples have been produced and evaluated for homogeneity and stability. All sample lots were homogenous ( $p$ value $>0.05$ ). All parameters of simulated urine were stable in 3 months at $-20^{\circ} \mathrm{C}$ ( $p>0.05$ ). However, at $2-8^{\circ} \mathrm{C}$ LEU and BIL were stable in 6 weeks, URO was stable in 8 weeks, the other 